\title{
PLASMA LH AND PROGESTERONE LEVELS AFTER SINGLE OR MULTIPLE INJECTIONS OF SYNTHETIC LH-RH IN ANOESTROUS EWES AND COMPARISON WITH LEVELS DURING THE OESTROUS CYCLE
}

\author{
D. B. GRIGHTON, J. P. FOSTER, W. HARESIGN \\ AND SUSAN A. SCOTT \\ Department of Physiology and Environmental Studies, \\ University of Nottingham School of Agriculture, \\ Sutton Bonington, Loughborough, Leicestershire
}

(Received 20th November 1974)

It has been shown that administration of a single intravenous injection of 150 or $300 \mu \mathrm{g}$ synthetic LH-releasing hormone (LH-RH) to seasonally anoestrous Clun Forest ewes induced LH release in all animals and ovulation in the majority (Foster \& Crighton, 1973, 1974). The induced LH peak was, however, much smaller than that observed at oestrus (Foster \& Crighton, 1974). Luteal function, as assessed by peripheral plasma progesterone levels, was absent in the majority of treated animals (Crighton, Foster, Haresign, Haynes \& Lamming, 1973; Haresign, Foster, Crighton, Haynes \& Lamming, 1975), possibly because of an inadequate release of $\mathrm{LH}$ before ovulation. As an alternative means of administration to simulate more accurately the natural preovulatory $\mathrm{LH}$ peak, a single dose of $150 \mu \mathrm{g}$ LH-RH was administered subcutaneously or intramuscularly instead of intravenously, but a greater release of LH was not obtained (S. C. Barnett, J. P. Foster and D. B. Crighton, unpublished data). Similarly, increasing the dose of the single intravenous injection from 150 to 300 $\mu \mathrm{g}$ failed to increase the height of (110 \pm 20 and $118 \pm 16 \mathrm{ng} / \mathrm{ml}$ respectively) or area under (1839 \pm 398 and $2097 \pm 247 \mathrm{~mm}^{2}$ respectively) the induced $\mathrm{LH}$ peak (Foster \& Crighton, 1973).

The development of a radioimmunoassay for LH-RH-like activity (Jeffcoate, Fraser, Gunn \& Holland, 1974) allowed its simultaneous determination with that of LH in the jugular venous plasma of the sheep at oestrus (Crighton, Foster, Holland \& Jeffcoate, 1973). This work suggested that, in order to simulate the natural LH peak in anoestrous ewes, administration of synthetic LH-RH intravenously as a series of injections might be appropriate.

In the present work, two cyclic and nine anoestrous Clun Forest ewes were used during the summer and autumn of 1973, respectively. All ewes were placed with a colour-marked vasectomized ram in order to detect the occurrence of oestrus. The cyclic ewes were bled $(2 \mathrm{ml})$ from an indwelling jugular vein cannula at 4-min intervals from the onset of oestrus for $18 \mathrm{hr}$ for the purposes of two separate studies. Every fourth sample only was used for the present work.

The anoestrous ewes were allocated to two groups: (1) five animals received a 
single injection of $150 \mu \mathrm{g}$ synthetic LH-RH through a jugular vein cannula; (2) four animals received four injections each of $30 \mu \mathrm{g}$ synthetic LH-RH at 90-min intervals followed by a fifth injection of $30 \mu \mathrm{g} 5 \mathrm{hr}$ after the fourth. A total dose of $150 \mu \mathrm{g}$ was thus administered over a $9 \frac{1}{2}-\mathrm{hr}$ period. This sequence of injections was designed to mimic the pattern of natural discharge of LH-RHlike immunoreactivity previously observed at oestrus (Crighton, Foster, Holland \& Jeffcoate, 1973). All treated animals were sampled $(2 \mathrm{ml})$ from the jugular vein cannula at 15-min intervals for $1 \mathrm{hr}$ before and up to $12 \mathrm{hr}$ after the first or only injection of synthetic LH-RH. Plasma from all samples was stored at $-20^{\circ} \mathrm{C}$ for later assay of the $\mathrm{LH}$ concentration by a double-antibody radioimmunoassay (Foster \& Crighton, 1974). The standard used was NIH-LH-S17. In addition, blood samples $(10 \mathrm{ml})$ were taken from the treated ewes daily for 3 days before and 24 days after treatment and progesterone levels were measured by radioimmunoassay (Haresign et al., 1975).

Laparotomy was carried out on all treated ewes 4 days after treatment and the ovaries were examined.

The two ewes sampled at oestrus showed preovulatory LH peaks similar to those observed previously (Foster \& Crighton, 1974).

In each of the five anoestrous ewes treated with a single injection of synthetic LH-RH, the pattern of release following treatment (Text-fig. 1) was similar to that observed in ewes given identical treatment in previous experiments (Foster \& Crighton, 1974).

All four anoestrous ewes treated with the multiple-injection sequence responded to the initial dose of synthetic LH-RH with a rise in the LH level. There was an accelerated rate of rise following the second injection, followed

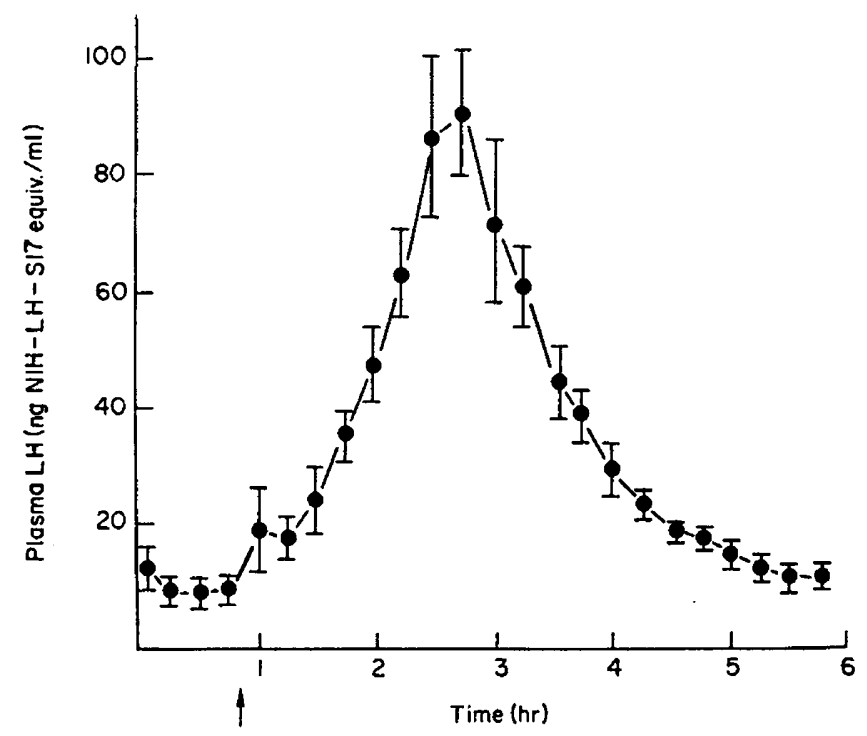

Text-pig. 1. Mean LH concentrations in the jugular venous blood of five ewes given a single injection of synthetic LH-RH. The arrow indicates the time of injection of $150 \mu \mathrm{g}$ LH-RH. Vertical bars represent the S.E.M. 


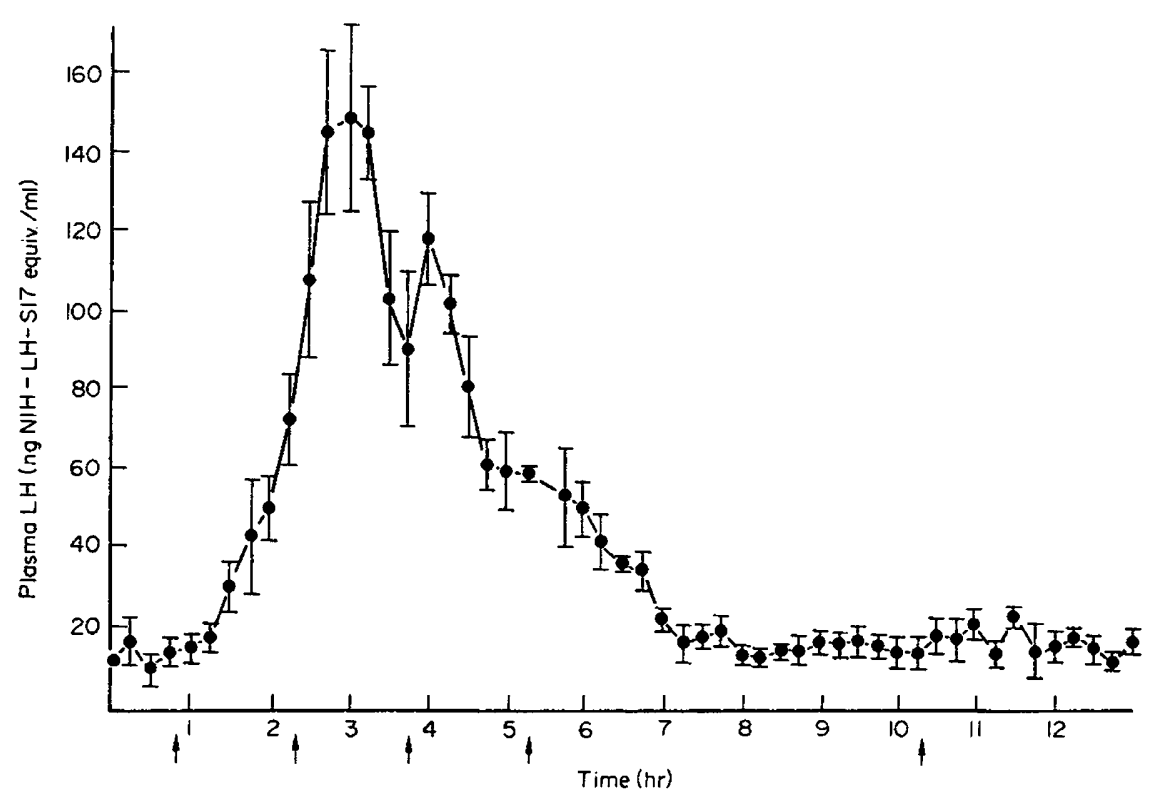

TExT-Fig. 2. Mean LH concentrations in the jugular venous blood of four ewes given multiple injections of synthetic LH-RH. The arrows indicate the times of injection of $30 \mu \mathrm{g} \mathrm{LH}-\mathrm{RH}$ (total dose $150 \mu \mathrm{g}$ LH-RH). Vertical bars represent the S.E.M.

by a decline in the LH level. Another elevation in plasma LH occurred following the third injection. Thereafter, the level fell to baseline (Text-fig. 2). The height of the $\mathbf{L H}$ peak induced by multiple injections was significantly greater than that induced by single injection $(172 \pm 16$ versus $98 \pm 12 \mathrm{ng} / \mathrm{ml}, P<0.01)$, as was the duration of $(6.87 \pm 0.87$ versus $4.30 \pm 0.22 \mathrm{hr}, P<0.05)$ and the area under $\left(7442 \pm 815\right.$ versus $\left.2477 \pm 279 \mathrm{~mm}^{2}, P<0.001\right)$ the peak. Since the peak levels were not reached at exactly the same time after injection in the individual animals, the mean heights of the $\mathrm{LH}$ peaks are different from the maxima shown in Textfigs 1 and 2. The LH release induced by multiple injections of LH-RH resembled the natural preovulatory $\mathrm{LH}$ release (height $159 \pm 24 \mathrm{ng} / \mathrm{ml}$, duration $8 \cdot 8 \pm 0 \cdot 62$ $\mathrm{hr}$, area $12,119 \pm 2719 \mathrm{~mm}^{2}$ ) more closely than that induced by a single injection. The results provide evidence, therefore, that the natural pattern of $\mathrm{LH}-\mathrm{RH}$ like immunoreactivity observed previously in jugular venous blood at oestrus (Crighton, Foster, Holland \& Jeffcoate, 1973) may indicate the natural discharge pattern of LH-RH from the hypothalamus, although it is also possible that the pattern observed could have been influenced by the pituitary. It is noteworthy that the lack of response to the fourth and fifth injections is in agreement with the finding that endogenous peaks of LH-RH-like immunoreactivity which occur after the natural LH peak at oestrus are not associated with further increases in the LH level (Crighton, Foster, Holland \& Jeffcoate, 1973). The doses of synthetic LH-RH used, however, may have resulted in non-physiological levels at the pituitary gland, thus making comparison of the natural and artificial situations hazardous.

When laparotomy was carried out 4 days after treatment, fresh ovulation 
points were visible in all five ewes given a single injection and in three of four ewes given multiple injections.

The plasma progesterone levels remained basal $(<0.4 \mathrm{ng} / \mathrm{ml})$ throughout the sampling period in seven of the nine treated ewes. In the remaining two ewes (single injection group), plasma progesterone levels began to rise 3 days after injection to reach maximum levels of 1.4 and $1.0 \mathrm{ng} / \mathrm{ml}$, falling again 10 to 12 days later. These levels were similar to those reported previously following LH-RH administration and are lower than the levels found during the luteal phase of the oestrous cycle (Crighton, Foster, Haresign, Haynes \& Lamming, 1973; Haresign et al., 1975).

Thus, despite the much larger release of $\mathrm{LH}$ induced by multiple injections of synthetic LH-RH compared with that induced by a single injection, normal luteal function did not result. Work is in progress to study this further.

Hormone preparations were provided by Hoechst Pharmaceuticals and the National Institutes of Health, U.S.A.

\section{REFERENCES}

Crighton, D. B., Foster, J. P., Haresign, W., Haynes, N. B. \& Lamming, G. E. (1973) The effects of a synthetic preparation of gonadotrophin releasing factor on pituitary and ovarian function in anoestrous ewes. F. Physiol., Lond. 231, 98p-99p.

Grighton, D. B., Foster, J. P., Holland, D. T. \& Jefrcoate, S. L. (1973) Simultaneous determination of luteinizing hormone and luteinizing hormone-releasing hormone in the jugular venous blood of the sheep at oestrus. $\mathcal{F}$. Endocr. 59, 373-374.

Foster, J. P. \& CRIGHTon, D. B. (1973) Preliminary observations on the administration of a synthetic preparation of gonadotrophin-releasing factor to cyclic and anoestrous ewes. F. Endocr. 57, xxv.

Foster, J. P. \& CRIGHTON, D. B. (1974) Luteinizing hormone (LH) release after single injections of a synthetic LH-releasing hormone (LH-RH) in the ewe at three different reproductive stages and comparison with natural $\mathrm{LH}$ release at oestrus. Theriogenology, 2 (in press).

Haresign, W., Foster, J. P., Crighton, D. B., Haynes, N. B. \& Lamming, G. E. (1975) Progesterone levels following treatment of seasonally anoestrous ewes with synthetic LH-releasing hormone. 7. Reprod. Fert. 43, 269-279.

Jeffcoate, S. L., Fraser, H. M., Holland, D. T. \& Gunn, A. (1974) Radioimmunoassay of luteinizing hormone-releasing hormone (LH-RH) in serum from man, sheep and rat. Acta endocr., Copenh. 75, 625-635. 